\title{
ANTIMICROBIAL AGENTS USED IN ENDODONTIC TREATMENT
}

\author{
Marina George Kudiyirickal, Romana Ivančaková
}

Charles University in Prague, Faculty of Medicine and University Hospital Hradec Králové, Czech Republic: Department of Dentistry

Summary: Biomechanical preparation alone does not completely eradicate microorganisms from the root canal, hence the next logical step is to perform root canal procedures in conjunction with antimicrobials. The use of an antimicrobial agent improves the efficacy and prognosis of endodontic treatment. This review enumerates the most widely used antimicrobial agents, their mechanism of action and their potential use in reducing the microbial load.

Key words: Antimicrobial agent; Microbial resistance; Antimicrobial irrigation; Endodontics

\section{Introduction}

Antimicrobials have a long heritage of usage for prevention of oral diseases (75). One of the ardent proponents of antiseptics has been W. D. Miller. He advocated the use of antiseptics for preventing caries as he had recognised the infectious character of tooth decay (79). In the subsequent years, following various research findings on the microbial etiology of oral diseases, there was a renewed interest in antimicrobial agents (6). The normal oral microflora comprises numerous bacterial species. However, the root canal environment is highly selective due to the limited availability of nutrients, complex bacterial interactions, and differences in oxygen potential in root canals with necrotic pulp. Hence the number of bacterial species which can survive in this harsh environment is comparatively less than that found in the oral cavity. The majority of the root canal microbiota therefore comprises facultative and strict anaerobic microorganisms which cause infections that stimulate periapical bone resorption, and are recalcitrant to endodontic treatment (104). Acute periradicular inflammation is mainly caused by anaerobes, especially black-pigmented Gram negative anaerobes $(88,121,138)$. The absence of bacteria during root canal filling enhances the endodontic prognosis $(45,46)$.

Root canal debridement and antimicrobial irrigation reduce the endodontic microbial load (15). Saline reduces the bacterial count during the manual instrumentation of canals. However, it does not result in negative cultures in a single visit (15), thereby emphasizing the significance of an antibacterial agent.

\section{Definition}

Antimicrobial agents may be disinfectants and antiseptics that destroy or inhibit the growth of microorganisms and thereby prevent infection by pathogenic or potentially pathogenic microorganisms. Disinfectants are used on inanimate objects or surfaces, whilst antiseptics are used on living tissues $(10,78)$.

\section{Classification}

Antimicrobial agents can be broadly classified into two groups: conventional antiseptics and chemotherapeutics (56).

Tab. 1: Classification of antimicrobial agents.

\begin{tabular}{|l|c|}
\hline Conventional antiseptics & Chemotherapeutics \\
\hline 1. Alcohols - Ethyl alcohol, Isopropylalcohol & Antibiotics \\
\cline { 1 - 1 } 2. Phenolic Compounds - Camphorated phenol, Monochlorophenol, Thymol, Cresol, Creosote & \\
\hline 3. Heavy Metal Salts & \\
\hline 4. Cationic Detergents - Quarternary ammonium compounds & \\
\hline 5. Halogens - Hypochlorite, Chloramine T, Iodine, Iodophores & \\
\hline
\end{tabular}

Adapted from Ingle JI, Bakland LK, 1994 


\section{General mechanism of action of antimicrobial agents}

The mechanism of action of antimicrobial agents is varied as they have multiple sites of action except for antibiotics, which have very specific sites of action. The nature of the organism, antimicrobial agent and the concentration determine the response of the microorganisms to the antimicrobials. Furthermore, with the involvement of multiple cell structures causing primary and secondary effect and cell lysis, it is difficult to determine the precise mode of action of these antimicrobial agents. The cell wall, cytoplasmic membrane and ribosomes of vegetative cells, the coat and cortex of bacterial spores, envelope and capsid of viruses and proteins (structural proteins, enzymes), nucleic acids and polysaccharides are some of the sites of action of antimicrobial agents. These antimicrobial actions eventually result in the loss of important cell functions like protein synthesis and metabolism, replication, transcription and destruction of cell membranes with leakage of cell contents (103).

\section{Efficacy of antimicrobial agents}

The two most important features which determine the efficacy of antimicrobial agents are the killing and the cleaning potential of the agent. The antimicrobial activity may vary from inhibition of metabolism to destruction of the microorganisms. The specific target of action of antimicrobials is difficult to elucidate as antimicrobial agents act on multiple cell components, resulting in both primary and secondary effects, which in turn is hard to distinguish. However, a combination of several techniques can help solve this problem. For example if enzyme inactivation and/or if damage of the cell wall, respiratory apparatus, ribonucleic acid (RNA) or deoxyribonucleic acid (DNA) are involved, then it implies that the antimicrobial inhibits the metabolic activity of the microbe. Thus the target site of activity of the antimicrobial can be elucidated.

Culture-based methods are used to measure the number of surviving bacteria. However, viable but, non culturable, "VBNC"(65) are not represented. Hence the numbers of viable organisms measured by culture are less than their true population. These methods are still useful in measuring the microorganisms in the sample. These include modified cultivation-based methods (12), application of fluorescent dyes, analysis of respiratory activity using the tetrazolium salt 5-cyano-2,3-ditolyl tetrazolium chloride (CTC) (100) and staining with the fluorochromes contained in the Live/Dead BacLight Bacterial Viability Kit, which measures the metabolic activity of antimicrobialtreated bacteria (12). Some of the other techniques are measurement of the transmembrane potential with Rhodamine 123 or DiBAC4 (3), which is used to determine the antimicrobial-treated biofilms to utilise nutritional substrates (73) and indirect measurement of the metabolic activi- ty of antimicrobial-treated bacteria by (49) using microelectrodes to determine the redox potential in the biofilm. Methods like image analysis (132) are used to detect surface-associated, stained bacteria, while a confocal laser scanning microscope (CLSM) detects changes in the morphology of the biofilm resulting from antimicrobial treament. Scanning electron microscopy (SEM) is often used to analyse the surface associated biofilm before and after antimicrobial treatment. All these techniques are of immense use in determining the efficacy of the antimicrobial agent.

\section{Microbial Resistance}

Resistance mechanisms of biofilms and planktonic cells are dissimilar. In a study by Gilbert et al. (34), biofilms were found to be 10 to 1000 times less susceptible than planktonic cells to antimicrobial agents. This striking difference is due the different resistance mechanisms of biofilms. Resistance is defined as the ability of a microorganism to grow in the presence of high levels of an antimicrobial agent or to survive treatment with an antimicrobial agent. Microbial resistance is mainly of two types, intrinsic and acquired resistance. Intrinsic, or innate, resistance is the natural chromosomally determined resistance and physiological adaptation which is specific for a particular microorganism. Acquired resistance refers to the resistance resulting from mutations and the selection of resistant mutants from a population exposed to antimicrobial agents, or due to the incorporation of plasmids or transposons, which results in resistance to antimicrobials $(78,82)$. It is most likely that increased cell densities in biofilms result in the selection of spontaneously resistant mutants when exposed to sublethal concentrations of antimicrobials, while increased cell numbers cause a horizontal transfer of genes expressing resistance to antimicrobials (23). Various other mechanisms which explain microbial resistance include slow rate of growth of biofilm cells due to restricted availability of nutrients, the emergence of a biofilm-specific phenotype, stimulation of general stress response genes, the occurrence of persistent cells and physical and chemical diffusion-reaction barriers which limit occurrence the penetration of antimicrobials into the biofilm (23).

\section{Sodium hypochlorite}

The antimicrobial solution that has had extensive use in endodontics as a root canal antimicrobial is sodium hypochlorite $(\mathrm{NaOCl})$, in concentrations ranging from $0.5 \%$ to $5.25 \%$. This is due to its antimicrobial and dissolving effects on necrotic tissues (111). There is no consensus within the endodontic community regarding the most effective concentration of sodium hypochlorite to be used. However, a concentration of $2.6 \%$ to $5.2 \%$ has been found to have adequate tissue solvent activity. Sodium hypochlorite is a reducing agent with $5 \%$ of available chlorine. It acts as 
a lubricant, antiseptic agent, bleach and also dissolves tissue (39). However, the exact bactericidal mechanism remains obscure (25). It is suggested that the antibactericidal ability of $\mathrm{NaOCl}$ results from the formation of hypochlorous acid $(\mathrm{HOCl})$ when in contact with organic debris. $\mathrm{HOCl}$ exerts its effect by the oxidation of sulphydryl groups within bacterial enzyme systems, thereby disrupting the metabolism of the microorganism (111). Cvek $\mathrm{M}$ et al. in his study reported that flushing with sterile saline had poor antibacterial action (9\%) when compared to sodium hypochlorite $(25 \%)$. In addition, $0.5 \%$ or $5.0 \%$ sodium hypochlorite solutions showed similar antibacterial effects. Inadequate mechanical cleansing of root canals in teeth with immature roots cannot be overcome by increasing the concentration of the solution, as it can cause tissue damage (20). The antibacterial action of $\mathrm{NaOCl}$ is time dependent. In an in vivo study, Ringel et al. noted that in root canals of permanent teeth $2.5 \% \mathrm{NaOCl}$ had a more powerful antibacterial effect than $2 \%$ chlorhexidine gluconate, as $\mathrm{NaOCl}$ was a powerful solvent for necrotic and organic material (95). Naenni et al reported that only sodium hypochlorite showed effective necrotic tissue dissolution among $10 \%$ chlorhexidine, $3 \%$ and $30 \%$ hydrogen peroxide, $10 \%$ peracetic acid, $5 \%$ dichloroisocyanurate (NaDCC), and $10 \%$ citric acid. This finding assumes significance when other substitutes are used in place of $\mathrm{NaOCl}$ for endodontic irrigation (84).

An in vivo study was done by Ercan et al on $2 \%$ chlorhexidine gluconate and $5.25 \%$ sodium hypochlorite in infected root canals and he concluded that both chlorhexidine gluconate and sodium hypochlorite prevent microbial activity in non vital teeth with or without periapical pathologies (27). The main drawback of $\mathrm{NaOCl}$ is the toxicity to the periapical tissues $(26,50,125)$, bad odour, discolouration of dental equipment, and

destruction of permanent tooth follicles and oral mucosa. It can also cause pharyngeal oedema and oesophageal burns when unintentionally swallowed (104), so its replacement by chlorhexidine gluconate is being carefully studied by various investigators (88).

Sodium hypochlorite is not carcinogenic in animals (52). However it is mutagenic in Salmonella typhimurium and not in Bacillus subtilis (52). Chromosome aberrations are seen in Chinese hamster lung cells but not in human fibroblasts (52). In vivo experiments on mice have shown that sodium hypochlorite does not elicit micronuclei, aneuploidy, and chromosome aberrations in bone marrow cells (57). Morphological transformation (135) and SCEs (80) are seen in SHE cells. However, UDS (42) is absent when sodium hypochlorite is used.

\section{Chlorhexidine gluconate}

Chlorhexidine (CHX) is widely used in periodontal and endodontic treatment as an irrigant. There are various mechanisms of antimicrobial action for chlorhexidine. It at- taches electrostatically to negatively charged sites on bacteria and also to its cytoplasmic membrane. The leakage of intracellular material is due to the loss of osmotic balance by $\mathrm{CHX}$. The binding of $\mathrm{CHX}$ to hydroxyapatite and soft tissues changes their electrical field to compete with the binding of bacteria (46).

Cetrexidin (Vebas, San Giuliano, Milan, Italy) is another antiseptic agent that is being evaluated. It consists of $0.2 \%$ chlorhexidine gluconate and $0.2 \%$ cetrimide (22, 125). Cetrimide (cetiltrimethyl ammonium bromide), is a quarternery ammonium compound and a cationic detergent that is effective against many Gram positive and Gram negative bacteria (22).

A study on the antimicrobial effectiveness and cytotoxicity of 4 irrigant solutions, viz $5.25 \%$ sodium hypochlorite $(\mathrm{NaOCl}), 0.2 \%$ chlorhexidine gluconate plus $0.2 \%$ cetrimide (Cetrexidin ${ }^{\circledR}$ ), $2 \%$ chlorhexidine gluconate and $0.9 \%$ sterile saline solution demonstrated that $\mathrm{NaOCl}$ should remain in the canal for a substantial period so that it can act upon the bacterial cells located in the irregularities within the canal. In this study, 5 minutes following the irrigation process, chlorhexidine gluconate had a more rapid and stronger action on E. faecalis than $\mathrm{NaOCl}$. Similar results were also obtained by D'Arcangelo et al. (22) and Türkün et al. (125). In the study it was seen that Cetrexidin ${ }^{\circledR}$ had a greater antibacterial effect than $5.25 \% \mathrm{NaOCl}$. A plausible explanation for this seems to be that cetrimide acts as a detergent, thereby lowering the surface tension. Cetrimide, when combined with chlorhexidine, easily penetrates into the root canals and dentinal tubules. However, no significant difference between the antibacterial effects of Cetrexidin ${ }^{\circledR}$ and $2 \%$ chlorhexidine gluconate was observed. Jeansonne \& White (58) found that chlorhexidine gluconate had a residual antibacterial effect on the infected canals and the antibacterial effect was substantive after $48 \mathrm{~h}$ of chlorhexidine and Cetrexidin ${ }^{\circledR}$ application into the E. faecalis inoculated canals (58).

$2 \%$ chlorhexidine gluconate and Cetrexidin ${ }^{\circledR}$ had more antibacterial effect on anaerobic bacteria than $5.25 \%$ $\mathrm{NaOCl}$. This was due to their active cationic properties, which enable their adsorbtion by the dentine surface and their residual antimicrobial activity. In vivo studies have reported that chlorhexidine has antibacterial activity with residual effects in the root canal for $48 \mathrm{~h}$. (72). Chlorhexidine appeared to be the most effective antibacterial substance in comparison to hydrogen peroxide, sodium hypochlorite and REDTA, while calcium hydroxide and saline solutions were least effective (99).

\section{Calcium hydroxide}

Calcium hydroxide is the most commonly used inter-appointment intracanal endodontic medicament (32, 91, 110, 120). The publication of research data on the antibacterial action of calcium hydroxide in root canal treatment by De Moor \& De Witte led to increased use of calcium hydroxide 
in endodontic treatment. Similar reports by several investigators resulted in widespread use of calcium hydroxide as an inter-appointment intracanal medicament $(89,112)$.

It is used as an intracanal medicament due to the healing of periradicular tissues. However, a few reports of adverse reactions have been found. $\mathrm{Ca}(\mathrm{OH})_{2}$ powder is made into a paste with water or saline and it is used as an intracanal dressing for a few days or weeks. The antibacterial activity is a result of free hydroxyl radical liberation (110) and diffusion of hydroxyl radicals resulting in a highly alkaline environment $(\mathrm{pH}$ 12.5). These hydroxyl ions penetrate the dentinal tubules and exert their effect. These hydroxyl radicals cause bacterial cell death by three possible mechanisms. The first mechanism is by splitting DNA strands and thereby preventing DNA replication and disrupting cellular activity $(55,97)$. Another method is by lipid peroxidation, which leads to the destruction of both phospholipid and cell membrane, finally resulting in loss of unsaturated fatty acids and massive destruction of membrane (68). The third mechanism is by protein denaturation and damage of cell metabolism. Calcium hydroxide also shows increased activity against anaerobes in comparison to paramonochlorophenol (32) and formocresol (120).

Resistance to $\mathrm{Ca}(\mathrm{OH})_{2}$ by certain microorganisms have been reported $(41,85,127)$. Nerwich et al. have shown differential diffusion rates of hydroxyl ions in cervical and apical root dentine (86). The $\mathrm{pH}$ of inner cervical root dentine peaked at 10.8 within hours after calcium hydroxide insertion, whilst apically a plateau $\mathrm{pH}$ of approximately 9.5 was reached only 2 weeks after the dressing was in place, and the outer root dentine $\mathrm{pH}$ reached a peak level of about 9.0 after 2-3 weeks.

In an extensive review of available clinical data on the efficacy of calcium hydroxide by C. Sathorn et al. was reported that calcium hydroxide has limited value as an antibacterial agent as evaluated by culture techniques (99). Ex vivo studies by Haapasalo et al. and Portenier et al. $(40,92)$ report that dentine may inactivate the antibacterial action of calcium hydroxide. Another study by Peters et al. (91) reported that the number of root canals positive for bacteria increased after intra canal medication with calcium hydroxide. Similar reports by other researchers also stated the inability of calcium hydroxide to effectively eradicate bacteria and the presence of positive cultures after using calcium hydroxide in the root canal $(91,94,128)$. Proton donors like $\mathrm{H}_{2} \mathrm{PO}_{4}, \mathrm{HCO}_{3}$ and $\mathrm{HCO}$ found within the dentine neutralize hydroxyl ions, thereby preventing the attainment of optimal microbicidal $\mathrm{pH}$ and compromising the antibacterial potential of calcium hydroxide $(86,129)$. In addition to this, necrotic tissue debris and/or cells may possibly interfere with the action of hydroxyl ions within the root canal and dentinal tubules (110).

\section{Hydrogen peroxide}

Another antimicrobial agent that has had extensive use in endodontics is hydrogen peroxide $\left(\mathrm{H}_{2} \mathrm{O}_{2}\right)$. The mecha- nism of action is by the reaction of superoxide ions, resulting in formation of hydroxyl radicals. Hydroxyl radicals are strong oxidants and they destroy membrane lipids, DNA and other essential cell components. The oxidation of sulphydryl groups and double bonds in proteins, lipids, and surface membranes is responsible for the antimicrobial action. In addition, the chloride in the bacteria may be oxidized to hypochlorite when myeloperoxidase enzyme is present (11).

Hydrogen peroxide is an oxidizing solution and is usually used in combination with sodium hypochlorite for root canal irrigation. This results in two kinds of reactive oxygen species, the superoxide anion radical $\left(\mathrm{O}_{2}^{-}\right)$and the hydroxyl radical $\left(\mathrm{OH}^{-}\right)$. Shiozawa $\mathrm{A}$. studied the $\mathrm{pH}$ changes and dissolved oxygen values in the $\mathrm{NaClO}-\mathrm{H}_{2} \mathrm{O}_{2}$ reaction mixture and found that the $\mathrm{pH}$ influenced the $\mathrm{O}_{2}^{-}$and $\mathrm{OH}^{-}$formation, and that $\mathrm{H}_{2} \mathrm{O}_{2}$ resulted in $\mathrm{O}_{2}$ formation. Root canal irrigation with $\mathrm{NaClO}$ and $\mathrm{H}_{2} \mathrm{O}_{2}$ induces both biological and mechanical effects. The biological effect of $\mathrm{NaClO}$ and $\mathrm{H}_{2} \mathrm{O}_{2}$ owes to tissue irritation due to the chemical reactions of $\mathrm{O}_{2}^{-}$and $\mathrm{OH}^{-}$, while the mechanical effect results from $\mathrm{O}_{2}$ bubbling (109). The effervescent action resulting in the release of nascent oxygen results in the agitation of the root canal contents and the debris is flushed out. The tissue dissolution and antimicrobial effect are the main mode of action of the combined solutions (18). The final irrigation of the canal should be done with sodium hypochlorite, as hydrogen peroxide can form gas in the presence of necrotic debris and blood leading to pain (39).

Concentration of $\mathrm{H}_{2} \mathrm{O}_{2}$ and irradiation time resulted in variation in the generation of hydroxyl radical from $\mathrm{H}_{2} \mathrm{O}_{2}$ exposed to light or laser radiation. Irradiation time also influenced the quantity of 5,5-dimethyl-1-pyrrolidone-(2)oxyl-(1) (DMPO-X). The amounts of hydroxyl radicals generated from $\mathrm{H}_{2} \mathrm{O}_{2}$ after irradiation were highest with a plasma lamp and lowest with a Yellow He-Ne laser. The amounts of DMPO-X generated from $\mathrm{NaClO}$ after irradiation was greater with a plasma lamp and least with a He-Ne laser (64).

\section{Formocresol}

Formocresol consists of formalin and tricresol in a ratio of 1:1. Tricresol is a combination of o-, m-, and p-cresols. The application time and the concentration of formocresol influence the histologic reaction of vital pulp. Formocresol is a bactericidal agent and the mode of action is by fixation, which results in inhibition of bacteria. Formocresol causes zones of necrosis, fixation, and inflammation. It results in healing with inflammation and eventual replacement with granulation tissue, bone or osteodentin in some cases.

Smith et al. (113) and various other investigators have stated that clot formation replaced the pulp tissue when ferric sulfate was used. Inflammation and calcific changes in the coronal as well as in the radicular portions of the pulp were some of the other findings in their studies (113). 
Cochrane Review (83) and evidence-based assessment of clinical trials of ferric sulphate and formocresol pulpotomies with meta-analysis (31) have reported similar clinical and radiographic success rates for both these agents.

Formaldehyde causes carcinogenesis in animals, mutation in bacteria, yeasts and Drosophila melanogaster and clastogenesis in mammalian cells and plants (51). Salmonella mutagenicity tests also reveal that formalin is mutagenic (13), while tricresol is non-mutagenic (44). Formaldehyde and m-cresol cause morphological transformation (135) chromosome aberrations (48), and UDS (42) in SHE cells. Formocresol also induces morphological transformation, UDS, and SCEs in SHE cells (122).

Formaldehyde is an ingredient in Buckley's Formocresol solution which is extensively used as a pulpotomy agent in grossly decayed deciduous teeth. In June 2004, the International Agency for Research on Cancer (IARC) classified formaldehyde as having carcinogenic potential in humans, as there is sufficient evidence which reveals that it causes nasopharyngeal cancer, limited evidence for cancer of the nasal cavity and paranasal sinuses, and 'strong but not sufficient evidence' for leukaemia (57).

\section{Ferric sulphate}

Ferric sulphate (15.5\%) is commonly used as a haemostatic agent in pulpotomy procedures. Landau and Johnsen in 1988 were the first who conducted animal experiments using ferric sulphate prior to the placement of calcium hydroxide over amputated pulps in monkey teeth. The persistence of an extrapulpal blood clot attributed to the decreased efficiency of calcium hydroxide. They studied the role of haemostasis by ferric sulphate and the resultant improvement in treatment with calcium hydroxide (71). The mode of action is by the formation of a ferric ion protein complex in the presence of blood resulting in the mechanical sealing of cut vessels by the membrane of this complex. This ultimately leads to haemostasis (102). The agglutinated protein complex forms plugs which seal the capillary orifices and inhibit clot formation $(28,70)$.

Several studies have been reported with the use of $15.5 \%$ ferric sulphate. In an experimental study, ferric sulfate, diluted formocresol and IRM, when used on pulpotomized primary teeth of baboons, the degree of inflammation, periradicular or interradicular abscess or inflammatory root resorption and presence of dentinal bridge were similar.

Thus the pulpal reaction of ferric sulfate and formocresol did not differ from each other (31). Similar results were obtained for ferric sulphate and formocresol in rat teeth by Cotes and co-workers (19). However, less than $40 \%$ of treated teeth presented with reparative dentine and fibrosis with ferric sulphate. A one-year prospective human trial (30) by Fei et al. revealed a success rate of $96 \%$ for ferric sulphate and $78 \%$ for formocresol on the basis of combined clinical and roentgenographic features. Investigations by Ibricevic and Al-Jame revealed similar success rates to that of Fuks et al. with ferric sulphate and formocresol treated teeth at an interval of 20 months (54) and subsequently at 48 months (53). However, the radiographic success rates decreased during this period from $97.2 \%$ to $92 \%$ for ferric sulphate. These results were significantly greater than that in the retrospective studies by Burnett and Walker (14) and Smith et al. (113). Casas et al. (16) used $16 \%$ ferric sulphate equivalent in an aqueous vehicle and compared this with pulpectomy in primary molars. A higher success rate was reported after 2 years for ferric sulphate than with pulpectomy. However, the sample size after 3 years was inadequate to demonstrate statistically significant success rates for ferric sulphate.

Ferric sulphate is less toxic than formocresol and hence it may be considered as an alternative to formocresol for pulp therapy in primary molars (54). Dental caries involving greater than half the inter-cuspal distance demonstrated inflammation of the pulp horn. Thus extirpation of coronal pulp alone would be adequate, thereby maintaining vitality of the radicular tissue rather than tissue fixation, which is achieved by formocresol. As ferric sulphate causes only haemostasis, it is a more appropriate pulpotomy agent and may be considered a good replacement for formocresol in pulpotomy (24).

Application of ferric sulfate as a hemostatic agent for long duration leads to persistent inflammation and delays osseous wound healing. However, with adequate curettage and irrigation of the osseous wound before closure, there was no significant difference in the persistence of inflammation or delay in osseous wound healing when compared with controls (58).

\section{Peracetic Acid}

Peracetic acid has a wide spectrum of antimicrobial action at low concentration, and within short duration (33, 38, 66, 67, 114, 115, 116, 117, 123, I. J. Hutchings and H. Xezone, unpublished data). Aqueous solution of peracetic acid (PAA) has high microbicidal activity against a broad range of microorganisms $(33,37,38,59,66)$. Peracetic acid is an effective germicide against bacteria, yeast, and viruses at $0.03 \%$ or lower concentration $(7,90)$. Alasri et al. state that when peracetic acid and hydrogen peroxide are used together, they have a combined action on biofilms owing to the microbicidal activity of peracetic acid and dettachment of biofilm by hydrogen peroxide (2).

The sporicidal action decreased with storage due to hydrolysis of peracetic acid, whereas it increased with high $\mathrm{pH}$ concentration. The drawback of high $\mathrm{pH}$ concentration is the carcinogenic potential of $1 \%$ peracetic acid, as it is a tumor promotor. The sporicidal action in a study by Jose-Luis and Aylin (98) was as follows: hypochlorite > peracetic acid $>$ copper-ascorbate $>$ glutaraldehyde $>$ peroxide $>$ phenol $>$ formaldehyde. Ageing, $\mathrm{pH}$, and temperature were found to greatly influence the order of the efficacy of these agents. Comet assay and Saccharomyces cerevisiae strain D7 stu- 
dies have shown that the lowest effective dose which caused genotoxicity in human leukocytes was $0.2 \mathrm{ppm}$ for chlorine dioxide, $0.5 \mathrm{ppm}$ for sodium hypochlorite and peracetic acid. One of the limitations of PAA is that it is known to cause corrosion. However, it is used as a surface decontaminant for foods. This is mainly because there is no surface adsorption of PAA and its by products like acetic acid, water, and oxygen are nontoxic and can be washed off easily $(38,74)$. The armamentarium for gnotobiotic studies is also sterilized using PAA $(9,124)$. According to Naenni $\mathrm{N}$ et al., among the commonly used endodontic irrigants like $10 \%$ chlorhexidine, $3 \%$ and $30 \%$ hydrogen peroxide, $10 \%$ peracetic acid, $5 \%$ dichloroisocyanurate (NaDCC), and $10 \%$ citric acid, all had lower tissue dissolution capacity in comparison to $1 \%$ (wt/vol) sodium hypochlorite $(\mathrm{NaOCl})(84)$.

\section{Chloramine T}

Chloramine $\mathrm{T}$ is N-chloro-p-toluensulphonamidesodium. It is used as an effective oral antiseptic agent. The mode of action is by the conversion of amino acids into aldehydes, carbon dioxide, ammonia and nitriles. Irrigation with a combination of hydrogen peroxide and chloramine, chloramine or glutaraldehyde were more effective irrigants than normal saline, $1 \%$ metronidazole or $3 \%$ hydrogen peroxide (138). A study by Wennberg A evaluated the cytotoxic effect in a cell culture system using HeLa cells and the initial tissue irritating effect of five antiseptics by applying the antiseptics onto an intact nonepithelialized tissue surface. 5\% Chloramine-T produced the greatest cell and tissue reactions, while $0.04 \%$ Jodopax, $0.1 \%$ Biosept, $0.1 \%$ Hibitane, or $0.5 \%$ sodium hypochlorite showed no differences in cell and tissue reactions. HeLa cell recovery was best following use of Jodopax, Chloramine-T or sodium hypochlorite solutions, whereas tissue recovery for Biosept and Hibitane were the best (130).

\section{Hexetidine}

Hexetidine is 1,3-bis(2-ethylhexyl)-5-amino-5-methyl-hexahydropyrimidine. Hexetidine is a good antibacterial and antifungal agent with a wide spectrum of activity both in vivo and in vitro. Hexetidine rinse is widely used as an antiplaque and antigingivitis, as it decreases supragingival plaque and gingival inflammation. In vitro and in vivo action against Gram-positive and Gram-negative bacteria as well as yeasts (Candida albicans) is well known (5, 96, 131). In addition, it is also used as an astringent, local anaesthetic and deodorant. It has not been widely used in endodontic treatment. Studies on in vitro oral biofilm models demonstrate that antimicrobials like chlorhexidine, hexetidine, delmopinol, amine fluoride/stannous fluoride, triclosan, and phenolic compounds interfere with bacterial metabolism and may inhibit biofilm development and maturation (6).
Biochemical properties of hexetidine include oxidation of intramitochondrial pyridine nucleotides and stimulation of the rate of oxygen uptake and inhibition of the rate of ATP synthesis. Thus hexetidine exhibits uncoupling of mitochondrial oxidative phosphorylation (21). In vitro and ex vivo experiments on the adherence of yeast cells to buccal epithelial cells (BEC) and in vitro morphogenesis showed that hexetidine caused decreased adherence of $C$. albicans to buccal epithelial cells and modified or inhibited the morphogenesis (60).

Although some microorganisms develop resistance to hexetidine, it is only temporary and does not last long (63). A concentration of $0.1 \% \mathrm{w} / \mathrm{v}$ when used as an oral rinse decreases the number of microorganisms. As the concentration of hexetidine in the oral cavity decreases with time there is a corresponding decrease in the antimicrobial effect. In an in vivo study, HPLC assay detected the presence of hexetidine in saliva up to $25 \mathrm{~min}$ after an oral rinse. This study also detected hexetidine below MICs for certain microorganisms (77). One of the advantages is that the extrinsic tooth staining is lower for hexetidine (107). Investigations testing the in vitro antifungal and fungicidal activities of antimicrobials demonstrated that cetylpyridinium chloride acheived significantly lower minimum inhibitory concentrations and had the maximum fungicidal activity in comparison to chlorhexidine digluconate and hexetidine (35).

\section{Aminefluoride}

$38 \%$ diamine silver fluoride, or $\mathrm{Ag}(\mathrm{NH} 3)_{2} \mathrm{~F}$, is used as a Nd:YAG laser initiator. Yokoyama $\mathrm{K}$ and co-workers reported that pulsed Nd:YAG laser or iontophoresis following $\mathrm{Ag}(\mathrm{NH} 3)_{2} \mathrm{~F}$ increased the permeability of the root canal wall and occlusion of dentinal tubules. Root canals treated using irradiation with an Nd:YAG laser that has been coated with $\mathrm{Ag}(\mathrm{NH} 3)_{2} \mathrm{~F}$ solution showed improved results compared to either iontophoresis after coating with $\mathrm{Ag}(\mathrm{NH} 3)_{2} \mathrm{~F}$ solution, or coating alone (137). In vitro studies have revealed that $\mathrm{CO}_{2}$ laser effectively removes or melts the smear layer of root canal walls after it is treated with $38 \%$ diamine silver fluoride $\left[\mathrm{Ag}(\mathrm{NH} 3)_{2} \mathrm{~F}\right]$ solution (29). Pulsed Nd:YAG laser irradiation for 2 sec after coating tooth surfaces with $38 \% \mathrm{Ag}(\mathrm{NH} 3)_{2} \mathrm{~F}$ solution prevents fracturing of endodontically treated teeth (136). $4 \%$ titanium tetrafluoride solution on root canal walls modified the smear layer on root canal walls, forming a massive structure which could not be eliminated with EDTA and/or $\mathrm{NaOCl}$ irrigations (136). The stability of this structure could be useful in preventing infection of dentinal tubules and microleakage, as it permanently occludes these tubules and avoids dissolution and disintegration of the smear layer (105). Biofilm inhibitory concentrations for chlorhexidine (300 times) and amine fluoride (75 times) is higher when Streptococcus sobrinus exists as a biofilm in contrast to the minimum bactericidal concentration for planktonic cells (106). 


\section{Cetylpyridinium chloride}

Cetylpyridinium chloride (CPC) is a quaternary ammonium salt $\left(\mathrm{C}_{21} \mathrm{H}_{38} \mathrm{ClN}\right.$; molecular weight, 358.07) having a combination of hydrophilic and lipophilic affinities. CPC is commonly used as a broad-spectrum antimicrobial against oral bacteria and with properties and uses typical of cationic surfactants. The primary mechanism of action of CPC is by cell membrane penetration, which results in leakage of cell contents, disturbance of bacterial metabolism and inhibition of cell growth. These eventually cause cell death (11, 101, 134). It exhibits surface-active properties. Thus the long duration of action is by virtue of the binding of $\mathrm{CPC}$ to the glycoproteins covering the teeth and oral mucosa. It does not alter the composition of the normal oral microbiota, which is in accordance with the American Dental Association (Council on Dental Therapeutics).

Cetylpyridinium chloride (CPC) is recognised as an effective antiplaque agent and commonly found in oral hygiene aids. It is less commonly used in root canal treatment. It is available as an over-the-counter drug regulated by the Food and Drug Administration (FDA) (1, 17, 61, 62, 69, $81,97,101,116,126)$ products. Mouthwashes and throat lozenges containing 1 to $2 \mathrm{mg}$ of CPC and the use of $1 \mathrm{loz}$ enge every 2 hours for adults and children above 6 years of age have been recommended. From April 2, 2004, the FDA permitted the use of a fine mist of CPC for antimicrobial action during the processing of poultry (level not to exceed $0.3 \mathrm{~g}$ of CPC per pound of poultry). Several animal studies $(4,36,93)$ on the cytotoxicity of CPC have shown it to be a highly safe and effective antimicrobial agent. Studies investigating incorporation of $2.5 \% \mathrm{CPC}$ in orthodontic adhesive have shown that antimicrobial properties are imparted by CPC, while the diametral tensile strength of the material remains the same. Slow and continuous release of CPC over a prolonged period has numerous clinical benefits. However, the maximum safe level for such slow release activity is unknown (3).

Investigations by various researchers have proved that cetylpyridiniumchloride (CPC) mouthrinses are effective anti-plaque agents, either when used alone or along with toothbrushing $(5,17,43,76,119,133,134)$. This has led the US Food and Drug Administration Dental Plaque Subcommittee to state that "it is reasonable to assume that formulations containing (at least) $72-76 \%$ available CPC are active in reducing plaque and gingivitis (Federal Register 2003)." However certain studies have shown that the antimicrobial action of CPC is inactivated by anionic surfactant substances like sodium lauryl sulphate (SLS) found in toothpaste $(17,108)$. The same applies to chlorhexidine rinses and hence a $30 \mathrm{~min}$. time span between toothbrushing and chlorhexidine has been suggested (8).

CPC has the distinction of being recognised by the FDA Plaque Subcommittee after a six year review of over 40 active ingredients as being one of the only three (stannous fluoride and essential oils - the remaining two safe agents) antimicrobial agents which is safe and effective (concentration range of 0.05 and $0.10 \%$ ) for the treatment of plaque-induced gingivitis. $(47,134)$.

\section{Conclusion}

The field of endodontics is rapidly changing with technological advances based on sound scientific research. A sterile endodontic canal is the cornerstone of successful treatment of infected root canals. It will facilitate ease in obturation and result in less post endodontic failures and complications. Hence the search for an ideal root canal antimicrobial agent which will completely eliminate endodontic pathogens from the root canal is one of the primary goals of endodontics.

\section{Acknowledgement}

This paper has been supported by the Grant Agency of Ministry of Education, Youth and Physical Training, no. 2B06104.

\section{References}

1. Addy M, Moran J. The effect of a cetylpyridinium chloride detergent foam compared to a conventional toothpaste on plaque and gingivitis. J Clin Periodontol 1989;16:87-91.

2. Alasri A, Moal, Roques J Fet al. De'sinfection d'un biofilm mixte: efficacite' compare'e du chlore, du formol, de l'acide perace'tique, du peroxyde d'hydroge 'ne et de l'association acide perace'tique/peroxyde d'hydroge 'ne. Science et Techniques de l'Eau 1992;461-67.

3. Al-Musallama Tahani A., Carla A. et al. Antimicrobial properties of an orthodontic adhesive combined with cetylpyridinium chloride. American Journal of Orthodontics and Dentofacial Orthopedics 2006;129(2): 245-51.

4. Arro L and C.R. Salenstedt, Evaluation of the toxicity of some quaternary ammonium compounds, J Biol Standardization 1973;1:11-22.

5. Ashley, K. C. The antimicrobial properties of two commonly used antisepticmouthwashes - Corsodyl and Oraldene. Journal of Applied Bacteriology 1984;56: $221-5$.

6. Baehni PC, Y Takeuchi. Anti-plaque agents in the prevention of biofilm-associated oral diseases. Oral Diseases 2003;9 (Suppl.1):23-29.

7. Baldry, M. G. C. The bacterial, fungicidal, and sporicidal properties of hydrogen peroxide and peracetic acid. J. Appl. Bacteriol. 1983;54:417-23.

8. Barkvoll, P., Rolla, G. \& Svendsen, K. Interaction between chlorhexidine digluconate and sodium lauryl sulfate in vivo. Journal of Clinical Periodontology 1989;16:593-5.

9. Barrett, J. P., Jr. Sterilizing agents for Lobound flexible film apparatus. Proc. Animal Care Panel 1959;9:127-33.

10. Block S. S. In: S. S. Block, $4^{\text {th }}$ ed. Disinfection, Sterilization, and Preservation Philadelphia: Lea and Febiger, PA, 1991:18-25.

11. Block S. S. Quaternary Ammonium Antimicrobial Compounds. In: Disinfection, Sterilization, and Preservation. In: S. S. Block, $4^{\text {th }}$ ed. Disinfection, Sterilization, and Preservation. Philadelphia: Lea and Febiger, PA, 1991:225-55.

12. Bredholt S, Maukonen, J., Kujanpa A et al. Microbial methods for assessment of cleaning and disinfection of food-processing surfaces cleaned in a low-pressure system. European Food Research and Technology 1999;209: 145-52.

13. Buck R., P. Eleazer and R. Staat. In vitro disinfection of dentinal tubules by various endodontics irrigants. J Endod 1999;25: 786-8.

14. Burnett S, Walker J. Comparison of ferric sulfate, formocresol and a combination of ferric sulfate/formocresol in primary tooth vital pulpotomies: a retrospective radiographic survey. ASDC Journal of Dentistry for Children 2002;69: 44-48.

15. Byström A, Sundqvist G Bacteriological evaluation of the efficacy of mechanical root canal instrumentation in endodontic therapy. Scandinavian Journal of Dental Research 1981;89: 321-8.

16. Casas MJ, Kenny DJ, Johnston DH, Judd PJ. Long-term outcomes of primary molar ferric sulfate pulpotomy and root canal therapy. Pediatric Dentistry 2004;26: 44-48. 
17. Ciancio, S. G., Mather, M. L. \& Bunnell, H. L. Clinical evaluation of a quaternary ammonium-containing mouthrinse. Journal of Periodontology 1975;46:397-401.

18. Cohen S, Burns RC. Pathways of the pulp. $7^{\text {th }}$ ed. Mosby, 1998: Irrigation Solutions 8:206.

19. Cotes O, Boj JR, Canalda C, Carreras M. Pulpal tissues reaction to formocreso vs. ferric sulfate in pulpotomized rat teeth. Journal of Clinical Pediatric Dentistry 1997;21: 247-54

20. Cvek M, Nord CE, Hollender L. Antimicrobial effect of root canal debridement in teeth with immature root. A clinical and microbiologic study. Odontol Revy. 1976;27(1):1-10

21. D'Arcangelo G, Barile M, Passarella S, Quagliariello E. Uncoupling of mitochondrial oxidative phosphorylation by hexetidine. Biochem Biophys Res Commun. 1987; 147(2):801-8

22. D'Arcangelo C, Varvara G, De Fazio P An evaluation of the action of different root canal irrigants on facultative aerobic-anaerobic, obligate anaerobic, and microaerophilic bacteria. Journal of Endodontics 1999;25: 351-3.

23. Davey, M. E. and O'Toole. Microbial biofilms: from ecology to molecular genetics. Microbiology and Molecular Biology Reviews. G. A. 2000;64: 847-67.

24. Duggal MS, Nooh A, High A. Response of the primary pulp to inflammation: a review of the Leeds studies and challenges for the future. Eur J Paediatr Dent. 2002;3(3):111-4

25. Dychdala, G. R. Chlorine and chlorine compounds. In: S. S. Block, $4^{\text {th }}$ ed Disinfection, Sterilization, and Preservation. Philadelphia: Lea and Febiger, PA, 1991:131-51.

26. Ehrich GD, Brian D, Walker WA. Sodium hypochlorite accident: inadvertent injection into the maxillary sinus. Journal of Endodontics 1993;19:180-2.

27. Ercan, Ertugrul, Ozekinci. Antibacterial Activity of $2 \%$ Chlorhexidine Gluconate and $5.25 \%$ Sodium Hypochlorite in Infected Root Canal: In Vivo Study.[Article] Journal of Endodontics. 2004:30(2):84-87.

28. Epstein E, Maibach HI. Monsel's solution: history, chemistry and efficacy. Archives of Dermatology 1964;90: 226-8.

29. Eto JN, Niu W, Takeda FH et al. Morphological and atomic analytical changes of root canal wall dentin after treatment with thirty-eight percent $\mathrm{Ag}(\mathrm{NH} 3) 2 \mathrm{~F}$ solution and CO2 laser. J Clin Laser Med Surg. 1999;17(1):19-24.

30. Fei A, Udin R, Johnson R. A clinical study of ferric sulfate as a pulpotomy agent in primary teeth. Pediatric Dentistry 1991;13: 327-32.

31. Fuks AB, Eidelman E, Cleaton-Jones P, Michaeli Y. Pulpal response to ferric sulfate, diluted formocresol, and IRM in pulpotomized primary baboon teeth Journal of Dentistry for Children 1997;64: 254-259.

32. Georgopoulou M, Kontakiotis E, Nakou M. In vitro evaluation of the effectiveness of calcium hydroxide and paramonochlorophenol on anaerobic bacteria from the root canal. Endod Dent Traumatol 1993;9: 249-53.

33. Gershenfeld, L., and Davis. D. E. Effect of peracetic acid on some thermoaciduric bacteria. Am. J. Pharm.1952;124:337-42.

34. Gilbert P, Das J, Foley I. Biofilm susceptibility to antimicrobials. Adv Dent Res 1997;11(1):160-7.

35. Giuliana G, Pizzo G, Milici ME, Giangreco R In vitro activities of antimicrobia agents against Candida species. Oral Surg Oral Med Oral Pathol Oral Radio Endod. 1999;87(1):44-9. Erratum in: Oral Surg Oral Med Oral Pathol Oral Radiol Endod 1999;87(4):524.

36. Green K., K. Bowman and R. Elijah, Dose effect response of the rabbit eye to CPC, J Toxicol Cutan Ocular Toxicol 1985;4:13-26.

37. Greenspan, F. P., Johnsen M. A., and. Trexler P. C. Peracetic acid aerosols. Chem. Specialties Mfrs. Assoc. Proc. Ann. Meeting 1955;42:59-64.

38. Greenspan, F. P, MacKellar D. G. The application of peracetic acid germicidal washes to mold control of tomatoes. Food Technol.1951;5:95-97.

39. Grossman L.I, Oliet S, Del Rio C. Endodontic practice 11th ed. Lea \& Febiger, 1988. Irrigation 11:189.

40. Haapasalo HK, Siren EK, Waltimo TM et al. Inactivation of local root canal medicaments by dentine: an in vitro study. International Endodontic Journal 2000;33:126-31.

41. Haapasalo M, Orstavik D. In vitro infection and disinfection of dentinal tubules. Journal of Dental Research 1987;66:1375-9.

42. Hamaguchi F, Tsutsui T. Assessment of genotoxicity of dental antiseptics: ability of phenol, guaiacol, p-phenolsulfonic acid, sodium hypochlorite, p-chlorophenol, m-cresol or formaldehyde to induce unscheduled DNA synthesis in cultured Syrian hamster embryo cells, Jpn. J. Pharmacol.2000;83:273-6.

43. Harper R, P., Addy, M., Moran, J et al. A comparison of chlorhexidine, cetylpyridinium chloride, triclosan, and C $31 \mathrm{G}$ mouthrinse products for plaque inhib tion. Journal of Periodontology 1996;67:486-9.

44. Haworth S, Lawlor T, Mortelmans K et al. Salmonella mutagenicity test results for 250 chemicals, Environ. Mutagen. Suppl.1983;1: 3-142.

45. Heling B, Shapira J. Roentgenologic and clinical evaluation of endodontically treated teeth, with or without negative culture. Quintessence International 1978;11:79-84.
46. Heiling I, Chandler NP. Antimicrobial effect of irrigant combinations within dentinal tubules. International Endodontic Journal 1998:31:8-14.

47. Herrera D, Santos S, Ferru's J et al. Efficacy of a $0.15 \%$ benzydamine hydrochloride and $0.05 \%$ cetylpyridinium chloride mouth rinse on 4-day de novo plaque formation. J Clin Periodontol 2005;32: 595-603.

48. Hikiba H, E. Watanabe, Barrett JC, Tsutsui T, Ability of fourteen chemical agents used in dental practice to induce chromosome aberrations in Syrian hamster embryo cells. J. Pharmacol. Sci.2005;97:146-152.

49. Holtmann, D. and Sell, D. Investigations into the application of a process for the determination of microbial activity in biofilms. Applied Microbiology and Biotechnology 2001;56:826-30.

50. Hülsmann M, Hahn W. Complications during root canal irrigation: literature review and case reports. International Endodontic Journal 2000;33:186-93.

51. IARC, Formaldehyde, IARC Monographs on the Evaluation of Carcinogenic Risk of Chemicals to Humans. International Agency for Research on Cancer, Lyon 1982;29: 345-389.

52. IARC, Hypochlorite salts, IARC Monograph on the Evaluation of Carcinogenic Risk to Humans. International Agency for Research on Cancer, Lyon 1991; 52:159-176.

53. Ibricevic H, Al-Jame Q. Ferric sulphate and formocresol in pulpotomy of primary molars: long term follow-up study. European Journal of Paediatric Dentistry 2003:4(1):28-32.

54. Ibricevic H, Al-Jame Q. Ferric sulfate as pulpotomy agent in primary teeth: twenty month clinical follow-up. Pediatric Dentistry 2000;24: 269-72.

55. Imlay JA, Linn S. DNA damage and oxygen radical toxicity. Science 1988;240:1302-9.

56. Ingle JI, Bakland LK. Endodontics. $4^{\text {th }}$ ed. Philadelphia: Lea and Febiger, 1994: 627-35.

57. International Agency for Research on Cancer. Press release no. 153. 15 June 2004. Evidence-based assessment: Evaluation of the formocresol versus ferric sulfate primary molar pulpotomy. Pediatric Dentistry 2004;26: 401-9.

58. Jeansonne BJ, White RR. A comparison of $2.0 \%$ chlorhexidine gluconate and $5.25 \%$ sodium hypochlorite as antimicrobial endodontic irrigants. Journal of Endodontics 1994;20, 276-8.

59. Jones, L. A., Hoffman R. K., and Phillips. C. R. Sporicidal activity of peracetic acid and, B-propiolactone at subzero temperatures. AppI. Microbiol. 1967:15:357-62.

60. Jones DS, McGovern JG, Woolfson AD, Gorman SP. The effects of hexetidine (Oraldene) on the adherence of Candida albicans to human buccal epithelial cells in vitro and ex vivo and on in vitro morphogenesis Pharm Res.1997;14(12): 1765-71.

61. Jenkins S., Addy M. and Newcombe R.G., A comparison of cetylpyridinium chloride, triclosan and chlorhexidine mouthrinse formulations for effects on plaque regrowth, J Clin Periodontol 1994;21: 441-44.

62. Jenkins S., Addy M. and Wade W. The magnitude and duration of the effects of some mouthrinse products on salivary bacterial counts. J Clin Periodontol 1994:21:397-401.

63. Kapic E, Becic F, Becic E. Ferric sulfate hemostasis: effect on osseous wound healing. II. With curettage and irrigation. Hexetidine-an oral antiseptic] Med Arh. 2002;56(1):43-8.

64. Kashima T M, Tsujimoto Y, Kawamoto K et al. Generation of free radicals and/or active oxygen by light or laser irradiation of hydrogen peroxide or sodium hypochlorite J Endod. 2003 Feb;29(2):141-3.

65. Kell, D. B., Kaprelyants, A. S., Weichart et al. Viability and activity in readily culturable bacteria: a review and discussion of the practical issues, Antonie van Leeuwenhoek, 1998;73:169-187.

66. Kline, L. B., and R. N. Null. The virucidal properties of peracetic acid. Am. J. Clin. Pathol.1960;33:30-33.

67. Koch, H. A. M. Sprossig. and H. Mucke. Untersuchungen zur fungiziden Wirkung der Peressigsaure. Pharmazie 1967;22:520-1.

68. Kohen R, Shalhoub R. Prevention and induction of oxidative damage in E. coli cells by cationized proteins. Free Radic Biol Med 1994;16: 571-80.

69. Kozlovsky A., Sintov A, Moldovan M, Tal H. Inhibition of plaque formation by local application of a degradable controlled release system containing cetylpyridinium chloride, J Clin Periodontol 1994;21:32-37.

70. Lemon RR, Steele PJ, Jeansome BG. Ferric sulfate hemostasis: effect on osseous wound healing. 1. Left in situ for maximum exposure. Journal of Endodontics 1993;19: 170-3.

71. Landau MJ, Johnsen DC. Pulpal responses to ferric sulfate in monkeys. Journal of Dental Research 1988;167: 215

72. Leonardo MR, Tanomaru F M, Silva LAB et al. In vivo antimicrobial activity of $2 \%$ chlorhexidine used as a root canal irrigating solution. Journal of Endodontics 1999;25:167-171.

73. Lisle, J. T., Pyle, B. H. and McFeters, G. A. The use of multiple indices of physiological activity to access viability in chlorine disinfected Escherichia coli O157:H7 Letters in Applied Microbiology 1999;29:42-47. 
74. Lowings P H. The fungal contamination of Kentish strawberry fruits in 1955 . Appl. Microbiol.1956;4:84-88.

75. Mandel ID. Chemotherapeutic agents for controlling plaque and gingivitis. J Clin Periodontol 1988;15:488-98.

76. Mankodi S, Bauroth K, Witt J. A six month clinical trial to study the effects of a cetylpyridinium chloride mouthrinse on gingivitis and plaque. American Journal of Dentistry 2005;18 (Special Issue):9A-14A.

77. McCoy CP, Jones DS, McGovern JG et al. Determination of the salivary retention of hexetidine in-vivo by high-performance liquid chromatography. J Pharm Pharmacol. 2000;52(11):1355-9.

78. McDonnell G, Russell AD. Antiseptics and disinfectants: activity, action, and resistance. Clinical Microbiology Reviews 1999;12:147-79.

79. Miller, W. D., The Microorganisms of the Human Mouth, S. S. White Denta Manufacturing Co., Philadelphia, 1890 (reprinted by S. Karger, Basel, 1973).

80. Miyachi T, Tsutsui T. Ability of 13 chemical agents used in dental practice to induce sister chromatid exchanges in Syrian hamster embryo cells. Odontology 2005;93:24-29.

81. Moran J., M. Addy R. Jackson and R. Newcombe. Comparative effects of quaternary ammonium mouthrinses on 4-day plaque regrowth. J Clin Periodontol 2000;27: 37-40.

82. Morton LHG., Greenway, DLA., Gaylarde C. C. and Surman S. B. Consideration of some implications of the resistance of biofilms to biocides. International Biodeterioration and Biodegradation 1998;41:247-59.

83. Nadin G, Goel BR, Yeung CA, Gleny AM. Pulp treatment for extensive decay in primary teeth. Cochrane Database ofSystematic Reviews 2003.

84. Naenni N, Thoma K, Zehnder M. Soft tissue dissolution capacity of currently used and potential endodontic irrigants. J Endod. 2004;30(11):785-7.

85. Nair R, Sjögren U, Krey G et al. Intraradicular bacteria and fungi in root-filled, asymptomatic human teeth with therapy-resistant periapical lesion: a long-term light and electron - microscopic follow-up study. Journal of Endodontics 1990; 16:580-8.

86. Nerwich A, Figdor D, Messer HH. pH changes in root dentin over a 4-week period following root canal dressing with calcium hydroxide. J Endod 1993; 19:302-6.

87. Nunoshiba T, Obata F, Boss AC et al. Role of iron and superoxide for generation of hydroxyl radical, oxidative DNA lesions, and mutagenesis in Escherichia coli. J Biol Chem 1999;274:34832-34837.

88. Ohara P, Torabinejad M, Kettering JD. Antibacterial effects of various endodontic irrigants on selected anaerobic bacteria. Endod Dent Traumatol. 1993;9(3):95-100.

89. Orstavik D, Kerekes K, Molven O. Effects of extensive apical reaming and calcium hydroxide dressing on bacterial infection during treatment of apical periodontitis: a pilot study. International Endodontic Journal 1991;24:1-7.

90. Orth R, Mrozeck H. Is the control of Listeria, Campylobacter, and Yersinia a disinfection problem? Fleischwirtschaft 1989;69:1575-6.

91. Peters LB, van Winkelhoff AJ, Buijs JF et al. Effects of instrumentation, irrigation and dressing with calcium hydroxide on infection in pulpless teeth with periapical bone lesions. Int Endod J 2002;35:13-21.

92. Portenier I, Haapasalo $\mathrm{H}$, Rye A et al. Inactivation of root canal medicaments by dentine, hydroxylapatite and bovine serum albumin. International Endodontic Journal 2001;34:184-8.

93. Quisno R., Foter M. Cetylpyridinium chloride. J Bacteriol 1946;52:111-17

94. Reit C, Molander A, Dahlen G. The diagnostic accuracy of microbiologic roo canal sampling and the influence of antimicrobial dressings. Endodontics and Dental Traumatology 1999;15:278-83.

95. 19. Ringel AM, Patterson SS, Newton $\mathrm{CW}$ et al. In vivo evaluation of chlorhexidine gluconate and sodium hypochlorite solutions as root canal irrigants. Journal of Endodontics 1982;8:200-4.

96. Roberts WR, Addy M. Comparison of the in vivo and in vitro antibacterial properties of antiseptic mouthrinses containing chlorhexidine, alexidine, cetylpyridinium chloride and hexetidine. Journal of Clinical Periodontology 1981; 8:295-310.

97. Rosa M. and O.P. Sturzenberger. Clinical reduction of gingivitis through the use of a mouthwash containing two quaternary ammonium compounds. J Periodontol 1976;47:535-7

98. Sagripanti JL and Bonifacino A. Comparative Sporicidal Effects of Liquid Chemical Agents Applied and Environmental Microbiology 1996;62(2):545-51.

99. Sathorn C, P. Parashos, H. Messer. Antibacterial efficacy of calcium hydroxide intracanal dressing: a systematic review and meta-analysis. International Endodontic Journal 2007;40 (1): 2-10.

100. Schaule, G., Flemming HC, Ridgway H. F. The use of CTC (5-cyano-2,3-ditolyl tetrazolium chloride) in the quantification of respiratory active bacteria in biofilms. Applied and Environmental Microbiology 1993;59:3850-7.

101. Scheie A. Modes of action of currently known chemical antiplaque agents other than chlorehexidine. J Dent Res 1989;68:1609-16.
102. Schröder U. A 2-year followup of primary molars pulpotomized with a gentle technique and capped with calcium hydroxide. Scandinavian Journal of Dental Research 1978;39:273-8.

103. Schulte S, Wingender J, Flemming HC. Directory of microbials for the protection of materials. In: Efficacy of biocides against biofilms. Springer Netherlands, 2004;1(5):93-120

104. Seltzer S, Farber PA. Microbiologic factors in endodontology. Oral Surgery, Oral Medicine and Oral Pathology 1994;78:634-45.

105. Sen BH, Buyukyilmaz T. The effect of $4 \%$ titanium tetrafluoride solution on root canal walls-a preliminary investigation. J Endod. 1998;24(4):239-43.

106. Shani S, Friedman M, Steinberg D. The anticariogenic effect of amine fluorides on Streptococcus sobrinus and glucosyltransferase in biofilms. Caries Res 2000: 34:260-267.

107. Sharma NC, Galustians HJ, Qaqish J et al. Antiplaque and antigingivitis effectiveness of a hexetidine mouthwash. J Clin Periodontol 2003;30:590-4.

108. Sheen, S., Eisenburger, M, Addy, M. Effect of toothpaste on the plaque inhibitory properties of a cetylpyridinium chloride mouth rinse. Journal of Clinical Periodontology 2003;30:255-60.

109. Shiozawa A. Characterization of reactive oxygen species generated from the mixture of $\mathrm{NaClO}$ and $\mathrm{H}_{2} \mathrm{O}_{2}$ used as root canal irrigants. J Endod. 2000;26(1): $11-15$

110. Siqueira JF Jr, Lopes HP. Mechanisms of antimicrobial activity of calcium hydroxide: a critical review. Int Endod J 1999;32:361-9.

111. Siqueira JF Jr, Machado AG, Silveira RM et al. Evaluation of the effectiveness of sodium hypochlorite used with three irrigation methods in the elimination of Enterococcus faecalis from the root canal in vitro. International Endodontic Journal 1997;30:279-32.

112. Sjögren U, Figdor D, Spangberg L, Sundqvist G. The antimicrobial effect of calcium hydroxide as a short-term intracanal dressing. International Endodontic Journal 1991;24:119-25.

113. Smith NL, Seale NS, Nunn ME. Ferric sulfate pulpotomy in primary molars: a retrospective study. Pediatric Dentistry 2000;22:192-9.

114. Sprossig. M. Uber die Eignung der Peressigsaure zur Kalt-sterilisation. Dtsch. Gesundheitswes.1970;22:1045-1048.

115. Sprossig M, Miucke H. Uber die antimikrobielle Wirkung der Peressigsaure. Untersuchungen zur viruziden Wirkung. Pharmazie 1968;23:665-7.

116. Sprossig. M, Miucke H. Uber die stark viruzide Eigenschaf't eines praktisch anwendbaren Alkohol -Peressigsaure-Gemisches. p. 1167 In JahreskongreB der Gesellschaft f'ur Seuchenschutz. Leipzig 1964;5:196

117. Sprossig. M, Miucke H, Tilgner PCH. Uber die ant imikrobielle Wirkung der Peressigsaure Untersuchungen zur bakteriziden und sporiziden Wirkung. Pharmazie 1967;22:517-19.

118. Steinberg D. Testing a degradable topical varnish of CPC in an experimental dental biofilm model. J Antimicrob Chemother 2001;48:241-3.

119. Stookey G K, Beiswanger B, Mau M et al. A 6-month clinical study assessing the safety and efficacy of two cetylpyridinium chloride mouthrinses. American Journal of Dentistry 2005; 18 (Special Issue):24A-28A.

120. Stuart KG, Miller CH, Brown CE et al. The comparative antimicrobial effect of calcium hydroxide. Oral Surg Oral Med Oral Pathol 1991;72:101-4.

121. Sundqvist G. Ecology of the root canal flora. Journal of Endodontics 1992; 18:427-30.

122. Suzuki H. Assessment of the carcinogenic hazard of 6 substances used in dental practice. Part II. Morphological transformation, DNA damage and sister chromatid exchanges in cultured Syrian hamster embryo cells induced by formocresol, iodoform, zinc oxide, chloroform, chloramphenicol, and tetracycline hydrochloride. Odontology 1987;74:1385-1403

123. Tichacek, B. P. 1966. Peressigsaure und die Moglichkeiten ihrer Verwertung in der Desinf'ektion. p. 2. Staatsverlag fur das Gesundheitswesen der CSSR. Prague.

124. Trexler PC, Reynolds LI. Flexible film apparatus for rearing and use of germfree animals. AppI. Microbiol.1957;5:406-12.

125. Türkün M, Gökay N, Özdemir N. Comparative investigation of the toxic and necrotic tissue dissolving effects of different endodontic irrigants. Journal of the Dental Faculty of Istanbul University 1998;32:87-94.

126. van der Mei H.C, Perdok JF, Genet M et al. Cetylpyridinium chloride adsorption on the wettability and elemental surface composition of human enamel. Clin Prev Dent 1990;12;25-29.

127. Waltimo T, Orstavik D, Sirén E, Haapasalo M. In vitro susceptability of Candida albicans to four disinfectants and their combination. International Endodontic Journal 1999;32:421-9.

128. Waltimo T, Trope M, Haapasalo M, Orstavik D. Clinical efficacy of treatment procedures in endodontic infection control and one year follow-up of periapical healing. Journal of Endodontics 2005;31:863-6.

129. Wang JD, Hume WR. Diffusion of hydrogen ion and hydroxyl ion from various sources through dentine. Int Endod J 1988;21:17-26. 
130. Wennberg A. Biological evaluation of root canal antiseptics using in vitro and in vivo methods Scand J Dent Res. 1980 Feb;88(1):46-52.

131. Wile DB, Dinsdale JR, Joynson DH. Hexetidine ('Oraldene'): a case report on its antibacterial and antifungal properties on the oral flora in healthy subjects. Curr Med Res Opin. 1986;10(2):82-88.

132. Wirtanen G, Mattila ST. Journal of Food Protection.1993;56:678-683.

133. Witt J, Ramji N, Gibb R et al. Antibacterial and Antiplaque Effects of a Novel, Alcohol-Free Oral Rinse with Cetylpyridinium Chloride. J Contemp Dent Pract 2005;1(6):001-009.

134. Witt, J. J., Walters, P., Bsoul S et al Comparative clinical trial of two antigingivitis mouthrinses. American Journal of Dentistry 2005;18 (Special Issue) $15 \mathrm{~A}-17 \mathrm{~A}$

135. Yamaguchi F, Tsutsui T. Cell-transforming activity of fourteen chemical agents used in dental practice in Syrian hamster embryo cells. J. Pharmacol. Sci. 2003;93:497-500.

136. Yokoyama K, Kimura Y, Matsumoto K et al. Preventive effect of tooth fracture by pulsed Nd:YAG laser irradiation with diamine silver fluoride solution. J Clin Laser Med Surg. 2001;19(6):315-18

137. Yokoyama K,, Murase J. Permeability of the root canal wall and occlusion of dentinal tubules by $\mathrm{Ag}(\mathrm{NH} 3) 2 \mathrm{~F}$ : a comparison of combined use with pulsed Nd:YAG laser or iontophoresis. J Clin Laser Med Surg. 2000;18(1):9-14.

138. Yoshida M, Fukushima J, Yamamato K et al. Correlation between clinical symptoms and microorganisms isolated from root canals of teeth with periapical pathosis. Journal of Endodontics 1987;13:24-28.

139. Zhi. Z K. An experimental study on cleaning efficacy of several root canal irrigants. 1991;26(4):205-7, 253

Submitted November 2007.

Accepted February 2008.

\section{Corresponding author:}

MUDr. Romana Ivančaková, CSc., University Hospital Hradec Králové, Department of Dentistry, Sokolská 581, 50005 Hradec Králové, Czech Republic, e-mail: ivancakovar@lfhk.cuni.cz 